Wine Politics 



\section{Wine Politics}

How Governments, Environmentalists, Mobsters, and Critics Influence the Wines We Drink

\section{Tyler Colman}

따

UNIVERSITY OF CALIFORNIA PRESS Berkeley · Los Angeles · London 
University of California Press, one of the most distinguished university presses in the United States, enriches lives around the world by advancing scholarship in the humanities, social sciences, and natural sciences. Its activities are supported by the UC Press Foundation and by philanthropic contributions from individuals and institutions. For more information, visit www.ucpress.edu.

University of California Press

Berkeley and Los Angeles, California

University of California Press, Ltd.

London, England

(C) 2008 by Tyler Colman

Library of Congress Cataloging-in-Publication Data

Colman, Tyler.

Wine politics : how governments, environmentalists, mobsters, and critics influence the wines we drink / Tyler Colman.

p. $\mathrm{cm}$.

Includes bibliographical references and index. ISBN 978-0-520-2552I-O (cloth : alk. paper)

I. Wine-Political aspects. 2. Wine industry.

I. Title.

HD9370.5.C65 2008

$338.4^{\prime} 76632-\mathrm{dc} 22$

2007032587

Manufactured in the United States of America
$\begin{array}{llllllllll}\text { I7 } & \text { I6 } & \text { I5 } & \text { I4 } & \text { I3 } & \text { I2 } & \text { II } & \text { IO } & 09 & 08\end{array}$
$\begin{array}{llllllllll}\text { IO } & 9 & 8 & 7 & 6 & 5 & 4 & 3 & 2 & \text { I }\end{array}$

This book is printed on Natures Book, which contains $50 \%$ post-consumer waste and meets the minimum requirements of ANSI/NISO Z39.48-I992 (R I997) (Permanence of Paper). 
To Michelle and Zander, with love 
